\title{
PSEUDOISOTACHIS POCSII VÁŇA, A NEW GENUS AND SPECIES OF LIVERWORT FROM THE SUBANTARCTIC MARION ISLAND
}

\author{
JIŘÍ VÁŇA
}

\begin{abstract}
A new genus and new species of liverwort, Pseudoisotachis Ván̆a and Pseudoisotachis pocsii Váňa, is described from Marion Island, part of the Prince Edward Islands, a subantarctic archipelago situated in the Kerguelen Province of the southern Indian Ocean. Family placement of the new genus and species is uncertain due to absence of androecia, gynoecia and sporophytes; morphologically it is compared with some genera of Isotachidaceae and with the genus Orthocaulis of Anastrophyllaceae. The new species is described and illustrated.
\end{abstract}

Key words: Pseudoisotachis, Marchantiophyta, Subantarctica, Marion Island, taxonomy

Jiři Ván̆a, Department of Botany, Charles University, Faculty of Sciences, Benátská 2, CZ-128 01 Praha 2, Czech Republic; e-mail:vana@natur.cuni.cz

\section{INTRODUCTION}

In the course of the study of liverworts collected by Professor Ryszard Ochyra (Kraków) in the subantarctic Marion and Prince Edward Islands, two specimens of an unknown liverwort species were detected. The plants resemble in habit some species of the genera Isotachis Mitt. and Orthocaulis (H. Buch) R. M. Schust., but they cannot be placed in either of these genera. Based on this fact, they are therefore described as both a genus and species new to science. It is my honour to dedicate the new genus and species to Professor Tamás Pócs, an outstanding bryologist and the renowned expert on African liverworts, in the occasion of his $80^{\text {th }}$ birthday.

\section{Pseudoisotachis pocsii Váňa, gen. et sp. nov.}

DESCRIPTION (DESCRIPTIO GENERICO-SPECIFICA). Plants creeping to suberect, scattered among mosses, $1-4 \mathrm{~cm}$ long and $0.8-1.5 \mathrm{~mm}$ wide, green, yellowish brown, but mostly chestnut brown to blackish brown, with no secondary reddish or vinaceous pigmentation. Shoots simple or with terminal Frullania-type branching (ventral branches not observed), stolons absent. Stem cross section 200 $300 \mu \mathrm{m}$ diameter, $12-14$ cells high, cortical cells in 1-2 layers, thick-walled, smaller than interior cells, 25-30 $\mu \mathrm{m}$, median cells thin-walled, without trigones or only with minute trigones, $35-45 \mu \mathrm{m}$; no mycorrhizal association found. Rhizoids colourless to pale yellowish, abundant, mostly restricted only to fascicles originating from underleaf bases, 11-13 $\mu \mathrm{m}$ wide. Leaves approximate to subimbricate, succubous, obliquely or subtransversely inserted, not decurrent, horizontally spreading to somewhat dorsally secund, concave to somewhat conduplicate (but never completely conduplicate as, e.g., in Balantiopsis), subquadrate to suborbicular or subreniform, with semiamplexicaul, shortly sheathing base, completely unistratose, $1.0-1.3 \times 1.2-1.4 \mathrm{~mm}, 2-3(-4)$-lobed to $0.3-0.5$ of the length; lobes broadly ovate to triangular, subapiculate to obtuse, rarely acute and distinctly incurved at apex, leaf sinus subacute to suborbicular, rarely acute, sometimes reflexed and gibbous, leaf margin sometimes with one or two small blunt basal teeth. Leaf cells nearly isodiametric, thinwalled, 30-45 $\mu \mathrm{m}$ diameter, with distinct trigones, basal cells somewhat elongated, up to 45-50 $\times 30-35 \mu \mathrm{m}$; cell surface papillose with ovate to elongate papillae. Underleaves large, $2-3 \times$ wider than stem, mostly up to $0.5(-0.6)$ bilobed, with 
additional 1-2 teeth on each side, rarely also 1-2 small teeth in the sinus; underleaf lobes widely to narrowly triangular. Gemmae not observed.

Plants dioicous (?, only young gynoecia observed). Female bracts wider than leaves, 2-3lobed, irregularly toothed with blunt teeth on each side and in sinus.

TyPE: SUBANTARCTICA. PRINCE EDWARD IsLANDS. MARION ISLAND: south-eastern coast. Middelrooikop between Black Haglet Valley and Soft Plume River, lat. $46^{\circ} 56^{\prime} 14^{\prime \prime} \mathrm{S}$, long. $37^{\circ} 48^{\prime} 59^{\prime \prime} \mathrm{E}$, alt. $360 \mathrm{~m}$; on dry bare soil between black lava boulders, 18 April 1999, R. Ochyra 1272/99 (HOLOTYPE: KRAM).

OTHER SPECIMEN SEEN (PARATYPE): SUBANTARCTICA. PRINCE EDWARD ISLANDS. MARION ISLAND: southern coast. In the northern part of Greyheaded Albatross Ridge west of Santa Rosa Valley, lat. $46^{\circ} 57^{\prime} 15^{\prime \prime} \mathrm{S}$, long. $37^{\circ} 42^{\prime} 32^{\prime \prime} \mathrm{E}$, alt. $340 \mathrm{~m}$; in sheltered site amongst black lava rock in dry situation on ground, 26 April 1999, R. Ochyra 2131/99 (KRAM).

ILLUSTRATIONS: Fig. 1: 1-28.

TAXONOMIC NOTES. The stem cross section, the form of the underleaves and the fascicles of rhizoids originating from the underleaf bases (not diffuse) and the large underleaves correspond well at least with some genera of the family Balantiopsidaceae. However, leaf insertion, orientation and form is somewhat different from all known species of that family, also cell structure (mostly isodiametric, not elongate thin-walled cells with trigones) is unusual for this family.

This new species is different from all known genera of the family. It is habitually similar to the genus Isotachis Mitt., but in that genus the leaves are incubous, as are those of the genus Hypoisotachis (R. M. Schust.) J. J. Engel \& G. L. S. Merr. The genus Eoisotachis R. M. Schust., characterized by it's somewhat succubous leaves, is subisophyllous and has entire to shallowly bilobed leaves and underleaves. Another segregate with slightly succubous leaves, Anisotachis R. M. Schust., has deeply bilobed leaves with narrowly ovate, apically truncate, suberect lobes and narrowly ovate underleaves, rhizoids are normally absent. In all the above genera the plants have at least partly vinaceous or reddish secondary pigmentation; the leaf cells are slightly thick-walled, without trigones, etc. The genus Acroscyphella N. Kitag. \& Grolle has brownish secondary pigmentation, succubous leaves as in this species, but the stem cross section is uniformly formed of thick-walled cells, branching is exclusively ventral-intercalary, leaf cells are firm-walled etc. The South American genus Ruizanthus R. M. Schust. has frequent ventral-intercalary stolons, symmetrically 3-4-lobed or 3-4-cuspidate leaves. Finally, the genus $\mathrm{Bal}$ antiopsis Mitt. has conduplicate leaves with lobe apices bidentate or shallowly bilobed, tending to be bisbifid, underleaves are ciliate etc.

On the other side, the habit and colour of the plants (brown, never reddish), leaf insertion and orientation (concave tending to be somewhat conduplicate, with gibbous sinus) and leaf form are similar to species of Orthocaulis (H. Buch) R. M. Schust. (= Barbilophozia subg. Orthocaulis H. Buch, Anastrophyllaceae); but form and size of the underleaves and fascicles of rhizoids limited to underleaf bases totally exclude the whole family. Finally, the secondary pigmentation never reddish and only in part brownish, the cell texture and underleaves with fascicles of rhizoids also agree with some members of the family Lophocoleaceae, but the orientation of leaves and somewhat unusual form of the underleaves exclude this family.

Unfortunately, because the examined plants have no antheridia and only young gynoecia (perianth or stem-perigynium not yet developed), the family and generic position remains uncertain. No similar species has ever been observed elsewhere in the Subantarctic or indeed in any other part of the world.

Fig. 1. Pseudoisotachis pocsii Ván̆a, sp. nov. 1 \& 3 - sterile plant, dorsal view, 2 - sterile plant, ventral view, 4 - stem crosssection, 5-12 - leaves, 13 - cells of leaf lobe, 14 - basal leaf cells, 15 \& 16 - leaf cross-sections, 17-23 - underleaves. 24 underleaf areolation, 25 - areolation of underleaf lobe, 26 - female bract 27 - female bracteole, 28 - areolation of bracteole lobe (all from $R O$ 1272b/99, holotype, KRAM). Scale bars: a - $1 \mathrm{~mm}(1)$; b - $100 \mu \mathrm{m}(28)$; c - $100 \mu \mathrm{m}(4,13-16,24 \& 25)$; $\mathrm{d}-1 \mathrm{~mm}(2 \& 3)$; e $-1 \mathrm{~mm}(5-12,26 \& 27)$. 


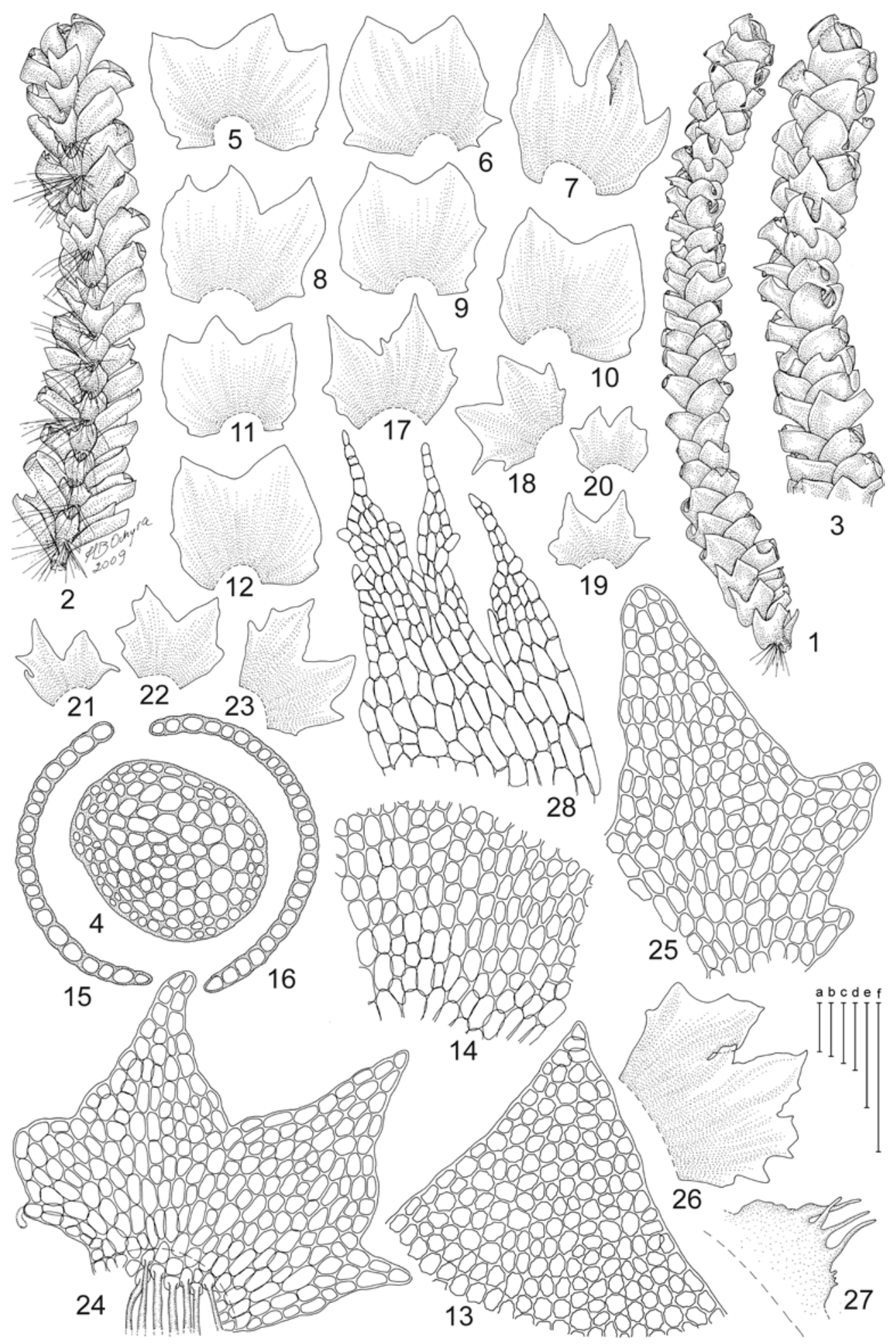


Differentiation. The large underleaves, as typically found in Balantiopsidaceae, clearly separate this species from all similar species of Lophozia s.l. (and their recent segregates); no other taxa of Balantiopsidaceae are present in the studied area.

DisTRIBUTION. Known only from Marion I.

There are several other relatively recently described taxa of liverworts known until now only from the Prince Edward Islands archipelago, viz. Andrewsianthus carinatus Grolle (Marion I.), Paracromastigium ryszardii Váňa, BednarekOchyra \& Cykowska (Marion I., Prince Edward I.), Riccardia crenuliformis R. M. Schust. (Marion I.), R. diversiflora subsp. paucigyna R. M. Schust. (Prince Edward I.), R. leptothallus R. M. Schust. (Marion I.), R. pauciramea R. M. Schust.
(Prince Edward I.), R. russellii R. M. Schust. (Prince Edward I.) and Scapania valdonii Ván̆a, Bednarek-Ochyra \& Cykowska (Prince Edward I.). It is tempting to suggest that further intensive collection in other areas of the eastern subantarctic islands (especially in the Crozet Is. archipelago) could reveal the real distribution of these taxa. Normally it would be considered highly unusual for endemic genera or even species to occur only in such a relatively young (less than one million years old) volcanic archipelago with volcanic activity as recently as 2004 .

ACKNOWLEDGEMENTS. The author expresses gratitude to Professor Halina Bednarek-Ochyra for the drawing of the new species, Professor Ryszard Ochyra for the possibility to study his collection of liverworts made on the Prince Edward Islands, and to Dr. David Long for the linguistic revision and some valuable comments. 